\title{
Amnésia social e representaç̃ōes de imigrantes: consequências do esquecimento histórico e colonial na Europa e na América๋
}

\author{
Karl Monsma* \\ Oswaldo Truzzi**
}

\section{Resumo}

Em vários países de imigração hoje, especialmente na Europa e na América do Norte, os "novos" imigrantes não europeus são vistos como mais problemáticos do que os imigrantes "históricos" da Europa. Geralmente, os movimentos e políticos anti-imigrantistas negam que sejam racistas, alegando que os novos imigrantes não aceitam os valores ocidentais, e que suas características culturais impedem a integração e produzem atitudes antidemocráticas, machistas e até terroristas. $\mathrm{O}$ artigo apresenta evidências históricas de que tal caracterização dos novos imigrantes, como se fossem portadores de uma alteridade insuperável, sem nenhuma relação com os países de imigração, só é possibilitada por duas formas de amnésia social: o esquecimento do tratamento sofrido por muitos imigrantes da periferia europeia no passado, e o esquecimento do passado colonial e neocolonial dos países de imigração. No passado, vários grupos imigrantes da periferia da Europa sofreram bastante hostilidade e estigmatização nos principais países de imigração. Também precisamos levar em conta o passado colonial para compreender as mudanças nos fluxos migratórios e as representações dos novos imigrantes, muitos dos quais não

\footnotetext{
* Universidade Federal do Rio Grande do Sul, Porto Alegre, RS. Brasil.

** Universidade Federal de São Carlos, São Carlos, SP, Brasil.

- Este texto foi escrito quando o primeiro autor era pesquisador visitante no Hamburger Institut für Sozialforschung (Hamburgo, Alemanha), cujo apoio agradecemos. O presente trabalho foi realizado com apoio da Coordenação de Aperfeiçoamento de Pessoal de Nível Superior - Brasil (CAPES).
} 
chegaram em grandes números antes, porque eram excluídos por políticas racistas de imigração. Distinguimos entre impérios de ultramar e impérios continentais, que muitas vezes incorporam povos conquistados como minorias nacionais e arbitrariamente dividem nações, redefinindo como "imigrantes" ou "ilegais" povos que migram dentro de seus próprios territórios. Argumentamos que a amnésia histórica e colonial não corresponde somente à vontade psicológica de deslegitimar os novos imigrantes; também é institucionalizada nos lugares e nas instituições da memória, que excluem da memória pública a integração dolorosa dos imigrantes da periferia europeia e as relações coloniais e neocoloniais entre os países de imigração e os territórios de origem dos novos imigrantes.

Palavras-chave: Imigração, Racismo, Colonialismo, Memória social.

\title{
Social amnesia and immigrant representations: consequences of historical and colonial oblivion in Europe and America
}

\begin{abstract}
In several countries of immigration today, especially in Europe and North America, the "new" non-European immigrants are seen as more problematic than the "historic" immigrants from Europe. Anti-immigrant movements and politicians generally deny that they are racists, alleging that the new immigrants do not accept western values, and that their cultural characteristics impede integration and produce antidemocratic, sexist and even terrorist attitudes. This article presents historical evidence that this characterization of the new immigrants, as if they were bearers of an insuperable alterity, completely unrelated to the countries of immigration, is only made possible by two forms of social amnesia: the forgetting of the treatment suffered by many immigrants from the European periphery in the past and the forgetting of the colonial and neocolonial past of the countries of immigration. In the past, several immigrant groups from the European periphery suffered hostility and stigmatization in the principal immigrant receiving countries. We also need to take the colonial past into account, in order to understand changes in migrant streams and the representations of the new immigrants, many of whom did not arrive in great numbers earlier, because they were excluded by racist immigration policies. We distinguish between overseas and continental empires, which often incorporated conquered peoples as national minorities and arbitrarily divide nations, redefining as "immigrants" or "illegal" peoples who migrate within their own territories. We argue that historical and colonial amnesia does not only correspond to the psicological need to delegitimate the new immigrants; it is also institutionalized in places and institutions of memory, which exclude from public memory the painful integration of immigrants from the European periphery and the colonial and neocolonial relations between the countries of immigration and the places of origin of the new immigrants.
\end{abstract}

Keywords: Immigration, Racism, Colonialism, Social memory. 
"Man hat Arbeitskräfte gerufen, und es kommen Menschen" ("Chamamos mão de obra, e chega gente") Max Frisch (1965)

citação acima do escritor suíço obviamente se refere ao fato de
que os países de imigração tratam os migrantes como simples
mão de obra, para ser chamada ou dispensada quando convier, dependendo dos ritmos da economia. Os migrantes, por outro lado, são seres humanos, que além de trabalhar, sentem, desejam, sonham e elaboram projetos para o futuro. Eles reivindicam direitos, trazem familiares, estabelecem-se permanentemente e desenvolvem atividades econômicas fora dos nichos inicialmente reservados para eles. Mas pode causar certo estranhamento ao leitor saber que a citação é do prefácio de um livro sobre os imigrantes italianos na Suíça na década de 1960. Hoje, na Europa, na América do Norte e também na América do Sul, os imigrantes vistos como "problemáticos" geralmente são os não brancos, ou não europeus, aqueles oriundos do Oriente Médio, da Ásia ou da África que chegam à Europa, os mexicanos e outros latino-americanos que chegam aos Estados Unidos, os bolivianos, haitianos e africanos que chegam ao Brasil ou os paraguaios e bolivianos que chegam à Argentina. Há um contraste que se elabora mais ou menos explicitamente na Europa e na América, entre os velhos imigrantes europeus, que supostamente se integraram sem grandes problemas, e os "novos" imigrantes não europeus, vistos como intrusos provenientes de regiões sem vínculo com a Europa, portadores de uma alteridade radical, atrasados e incapazes de se integrar em sociedades modernas e democráticas (Mbembe, 2014).

Este contraste comum - por exemplo, entre os poloneses e os turcos na Alemanha, entre os italianos e os argelinos na França, entre os irlandeses e os indianos no Reino Unido, ou entre todos os europeus e os mexicanos nos Estados Unidos - se baseia na amnésia histórica, numa projeção anacrônica ao passado da condição atual dos descendentes de grupos europeus relativamente bem integrados nos países para onde seus avós 
ou bisavós migraram. ${ }^{1}$ De fato, vários dos grupos imigrantes de origem europeia, hoje bem integrados e vistos como bons cidadãos, no passado foram racializados e vistos como problemáticos - "ladrões de empregos", inassimiláveis, sem lealdade ao novo país, criminosos, adeptos de ideologias extremistas, um ônus aos serviços sociais, portadores de doenças, vícios ou costumes imorais. Na estigmatização dos "novos" imigrantes como radicalmente diferentes e incapazes de se integrarem, a amnésia sobre a imigração histórica se combina com a amnésia a respeito do passado colonial, que afeta não somente os principais centros do colonialismo de ultramar, como a Inglaterra, a França ou a Espanha, mas também os países que não se pensam como colonialistas, como a Alemanha, os Estados Unidos ou o Brasil, que esquecem das colônias que dominavam no passado, além de adotarem atitudes originárias dos principais centros do colonialismo formal. O que é mais importante, vários desses países conquistaram impérios continentais, expulsando ou subordinando como minorias nacionais os povos que antes ocupavam as terras. Essas conquistas influenciam até hoje as atitudes a respeito dos descendentes dos conquistados.

Este artigo apresenta evidências históricas de que os "velhos" imigrantes da periferia europeia sofreram bastante discriminação e estigmatização, tanto na Europa como na América do Norte. Também apresentamos evidências de que o passado colonialista e imperialista da Europa e da América do Norte influencia as atitudes negativas a respeito dos imigrantes das antigas colônias. Isso é particularmente evidente nas representações de muçulmanos

\footnotetext{
${ }^{1}$ Um anacronismo semelhante distorce o trabalho de Anibal Quijano (2000), talvez o autor mais citado na América Latina com relação à racialização da América. Quijano alega que os europeus, na América, já tinham uma identidade "branca" consolidada pouco tempo depois da conquista, ignorando, ou desconsiderando, a evidência de que a obsessão com "pureza de sangue" começou na península ibérica e que, no início, era direcionada principalmente contra judeus, muçulmanos e seus descendentes, independentemente da cor da pele (cf. Fredrickson, 2002), além do fato de que as categorias fundamentais dos conquistadores eram religiosas, dividindo o mundo entre cristãos e os outros. Ao adotar esse anacronismo, Quijano e outros perdem a oportunidade de pesquisar a transformação de categorias religiosas em categorias raciais. Outra consequência é uma tendência de tratar o racismo como uma estrutura ideológica imutável, o que subestima radicalmente as contradições do racismo e suas mudanças ao longo do tempo.
} 
como fanáticos perigosos. Além do colonialismo de ultramar, chamamos a atenção para o colonialismo continental, muitas vezes negligenciado nos estudos sobre o tema, que envolve a conquista dos povos de territórios contíguos ao núcleo imperial, com a anexação de suas terras e a incorporação desses povos como minorias subordinadas. A partir dessas evidências históricas, desenvolvemos o argumento de que as representações dos "novos" imigrantes como ameaças aos valores e modo de vida "ocidentais" dependem do esquecimento da reação histórica contra os imigrantes da periferia europeia e também do esquecimento colonial. Alguns aspectos deste argumento também se aplicam ao Brasil e a outros países da América do Sul. Concluímos apontando que as instituições de memória social funcionam também como instituições de esquecimento, porque salientam alguns aspectos das histórias nacionais e desconsideram outros.

\section{A racialização e a estigmatização na história das migrações de europeus}

\section{Migrações dentro da Europa}

Quase todos os principais grupos de imigrantes da periferia europeia já foram racializados e estigmatizados nos países mais ricos do noroeste do continente: os poloneses na Alemanha, os italianos na França, na Holanda e na Suíça, os irlandeses na Inglaterra. Mas, com o passar do tempo, e em contraste com os "novos imigrantes" de fora da Europa, os descendentes dos velhos imigrantes europeus perderam o estigma e foram aceitos como cidadãos plenos dos países onde moram.

Talvez nenhum povo da periferia da Europa tenha sofrido uma racialização tão longa e intensa quanto a sofrida pelos irlandeses de parte dos ingleses. A Irlanda foi a primeira colônia inglesa, e sofreu expropriações de terras, restrições sociais e educacionais, e a repressão sangrenta de rebeliões, em muitos aspectos comparáveis com a dominação posterior da Inglaterra na Ásia e na África. Paralelamente com a dominação, os ingleses desenvolveram um conjunto de representações dos irlandeses como essencialmente inferiores, 
incivilizados e com pouca capacidade intelectual, sendo recorrentes ilustrações que os representavam como símios pálidos (Monsma, 2017). Desde a préhistória, sempre houve movimento entre as duas ilhas, mas a migração da Irlanda à Inglaterra se intensificou muito em decorrência da grande fome de meados do século XIX. Desde então, a migração de irlandeses para a Inglaterra é contínua, mas houve outra grande onda dessa migração durante e depois da Segunda Guerra. Com a falta de trabalhadores, depois da Segunda Guerra, a Inglaterra também importou um grande número de trabalhadores poloneses (Miles, 1993). Hoje, os descendentes dos imigrantes históricos da Irlanda e da Polônia são ingleses e quase não se questiona seu pertencimento à cultura nacional. Mesmo durante as três décadas do conflito violento na Irlanda do Norte (1968-1998), com vários atentados terroristas realizados pelo IRA na Inglaterra, não houve grande reação contra os milhões de descendentes de irlandeses com cidadania britânica. E hoje, com uma onda de crimes de ódio contra imigrantes poloneses e uma tendência dos trabalhadores ingleses de acusarem os poloneses de "roubarem nossos empregos", tal reação parece não atingir os descendentes assimilados de poloneses (Monsma, 2017).

Na Alemanha, é comum pensar que o país só nas últimas décadas se tornou um "país de imigração", o que é facilmente desmentido por qualquer lista de sobrenomes alemães ou ainda pela observação dos nomes dos negócios e escritórios profissionais em muitos bairros urbanos, sobretudo na região histórica de mineração e indústria pesada do vale do Ruhr. Muitos dos sobrenomes, em quase qualquer listagem de gente que se considera $100 \%$ alemã, são de origem polonesa, e outros são nomes italianos, tchecos, russos ou holandeses. Ainda outros descendentes de imigrantes passam desapercebidos, porque seus sobrenomes foram germanizados. O caso dos poloneses na Alemanha é discutido com mais detalhe na próxima seção.

Grande número de italianos migrou para a França a partir de meados do século XIX. A maior parte era composta de trabalhadores rurais que viraram proletários na França. Os trabalhadores franceses os viam como competidores e a população francesa, de maneira geral, os estereotipava como sujos e violentos. Aconteceram vários distúrbios violentos contra os italianos. Trinta 
deles foram linchados em Aigues-Mortes em 1893, depois de um conflito com trabalhadores franceses, e no ano seguinte as lojas de italianos em Lyon foram saqueadas, depois do assassinato do presidente Sadi Carnot nessa cidade por um anarquista italiano. Muito mais italianos chegaram no período entre as guerras, e os ataques contra eles continuaram. Além de serem vistos como "ladrões de empregos", eles eram considerados uma ameaça política, pela possível associação ao fascismo ou ao comunismo. A Segunda Guerra só exacerbou o preconceito contra os imigrantes italianos, que continuou na primeira década depois da guerra. Entretanto, até o fim da década de 1950, tal preconceito desapareceu e os descendentes de italianos foram plenamente aceitos como franceses. A integração dos italianos não foi fácil e levou tempo; parece que ajudou muito sua contribuição ao movimento operário e a militância compartilhada de trabalhadores italianos e franceses na primeira metade do século XX (Blanc-Chaléard, 2006). Vários outros grupos de imigrantes trilharam caminhos parecidos na França pós-guerra, da xenofobia à integração plena - espanhóis, portugueses, refugiados judeus, poloneses, armênios, russos.

\section{Imigrantes nos Estados Unidos}

Nos Estados Unidos o mosaico étnico dos imigrantes europeus era mais complexo, mas podemos dizer que somente os protestantes do norte da Europa escaparam da estigmatização. Durante um bom tempo no século XIX, todos os imigrantes católicos eram vistos com suspeita, sobretudo os irlandeses, que chegaram em grande número na época da grande fome, em meados do século, e ficaram relativamente concentrados nas cidades, em contraste com os católicos alemães, que eram mais dispersos. Alegava-se que os católicos deviam obediência a uma potência estrangeira (o Vaticano) e, portanto, não podiam ser bons cidadãos. Em meados do século, um movimento social, os Know Nothings - conhecido assim por sua organização sigilosa, formou-se para combater a imigração católica e a suposta conspiração católica para tomar o poder nos Estados Unidos para o Papa. Os Know Nothings promoveram investidas violentas de gangues de protestantes contra bairros irlandeses e 
escolas católicas. Também pressionaram, sem sucesso, por leis que barrassem a imigração irlandesa e proibissem a eleição de imigrantes naturalizados a cargos públicos. Formaram um partido político, o American Party, e ganharam várias eleições em nível municipal e estadual (Gerstle, 2015; Lipset; Raab 1978). A noção, essencialmente protestante, de "destino manifesto", de que os Estados Unidos haviam sido eleitos por Deus para expandir-se até o Pacífico, também serviu como justificativa para a guerra contra o México católico e a anexação da metade do território mexicano na década de 1840 (Gerstle, 2015).

Ao final do século XIX muitos católicos chegaram aos Estados Unidos, vindos do leste e do sul da Europa, especialmente da Polônia e da Itália, junto com novas levas de católicos irlandeses e alemães. Por muito tempo, os imigrantes irlandeses, latinos e eslavos, junto com os judeus, não eram considerados "brancos" pelos protestantes com raízes no norte da Europa, e tiveram de empreender longas lutas para serem aceitos como brancos (Jacobson, 1998). As elites protestantes levantaram uma ampla variedade de acusações contra os católicos, vistos como bêbados, subversivos da moralidade protestante e corrompidos por políticos que forneciam empregos e serviços em troca do voto étnico. Os imigrantes do sul e leste da Europa também eram vistos como anarquistas ou socialistas (FitzGerald; Cook-Martín, 2014, p. 98-9). Além do mais, contra os italianos pesavam as acusações de se misturarem com os negros - o que, para os protestantes brancos, provava sua inferioridade racial - e de não serem preparados para a cidadania democrática, porque suas lealdades familiares eram mais fortes do que sua lealdade à nação (Jacobson, 1998). Neste ambiente em que os protestantes temiam perder o controle das cidades e dos seus próprios filhos e filhas, formavam-se "sociedades antivícios" em várias cidades, dedicadas à defesa da "civilização cristã", por meio da censura de obras de arte e livros considerados obscenos e da proibição de contraceptivos (Beisel 1997). Também havia a mobilização de nativistas, junto com médicos, para proibir o aborto - antes disso não criminalizado - para limitar a queda na fertilidade das mulheres protestantes, que estavam produzindo menos filhos do que as católicas (Beisel; Kay 2004). 
Como é comum neste tipo de conflito, havia certa tensão entre os capitalistas, que precisavam de trabalhadores imigrantes, e os nativistas, que podiam ser trabalhadores ameaçados pela competição dos imigrantes ou elites que queriam manter a suposta homogeneidade étnica e racial do país. Finalmente, em 1924, os nativistas conseguiram passar uma lei de cotas de imigração que favorecia os países do noroeste europeu e limitava a imigração do leste e do sul do velho continente, porque as cotas se baseavam nos números de imigrantes de cada origem que já moravam no país em 1890, antes da grande onda de imigração daquelas regiões da Europa. Esta lei também serviu para limitar a imigração de judeus, a grande maioria dos quais era proveniente da Rússia ou do leste europeu. É interessante notar que a lei não limitou a imigração da América Latina, em parte porque muitos fazendeiros, agricultores e outros empregadores do sudeste do país dependiam do trabalho de mexicanos, considerados migrantes temporários ou sazonais, em parte também porque os Estados Unidos não queriam antagonizar os governos da região, para não perder influência e dar abertura a maior domínio europeu ou soviético - afinal, o México havia passado por um processo revolucionário poucos anos antes e aceitar os migrantes mexicanos era uma maneira de manter alguma influência sobre o país vizinho. Poucos anos depois, as cotas foram ajustadas para refletir as proporções de descendentes de imigrantes de cada nação europeia presentes no momento do censo de 1920, o que pouco as alterou (FitzGerald; Cook-Martín, 2014, p. 101-2; Volpp, 2005).

No Brasil, a constituição de 1934 adotou um sistema de cotas baseado no sistema dos Estados Unidos, limitando a imigração anual de cada nacionalidade a $2 \%$ do número total de imigrantes da mesma origem nos 50 anos anteriores. Por um lado, as cotas protegiam os brasileiros no mercado de trabalho; por outro, favoreciam os imigrantes europeus, quase proibiam a entrada de africanos e limitavam severamente a imigração de japoneses. Ao mesmo tempo, o Brasil usou medidas administrativas para restringir a entrada de refugiados judeus (FitzGerald; Cook-Martín, 2014). A constituição da Argentina estabeleceu uma preferência para imigrantes europeus, mas não estabeleceu um sistema de cotas nacionais e somente 
proibiu a imigração de "ciganos", preferindo usar a discrição administrativa para selecionar os imigrantes, aparentemente para não chamar a atenção internacional para políticas discriminatórias (FitzGerald; Cook-Martín, 2014).

Tanto na Europa como na América, a amnésia a respeito da imigração do passado leva à tendência de se exagerar as diferenças entre a imigração velha, principalmente europeia, e a nova imigração. Na Europa, os velhos imigrantes ficaram tão invisíveis que é até comum afirmar que esses países só agora estão virando "países de imigração". Os descendentes de poloneses, italianos ou portugueses são aceitos como nativos dos países onde moram, e participam nos movimentos contra a imigração de não europeus, sobretudo de muçulmanos, cuja religião é vista como atrasada, machista e incapaz de aceitar a convivência democrática com outras religiões. Esta amnésia a respeito da imigração do passado não pode ser atribuída às particularidades de histórias nacionais específicas - como faz Noiriel (1995), por exemplo, a respeito da França - porque tal amnésia é geral, ocorrendo em países de tradições e culturas muito distintas.

Nos Estados Unidos, integrantes de grupos étnicos como os irlandeses, os italianos e os judeus, que sofreram forte racialização e estigmatização no passado, todos lutaram para serem aceitos como brancos plenos, geralmente em contraste com os negros, com os mexicanos e com os habitantes das colônias que o país conquistou da Espanha na guerra de 1898 (Jacobson, 1998). Hoje, muitos descendentes desses imigrantes afirmam que mexicanos roubam empregos e se aproveitam de serviços sociais pagos pelos impostos dos cidadãos. É como se estes grupos reafirmassem sua branquitude pelo fortalecimento da fronteira entre os "brancos" e os outros. Ou seja, a amnésia a respeito da racialização de vários grupos europeus no passado facilita a consolidação da identidade branca desses grupos e fortalece a solidariedade dos brancos.

\section{A amnésia colonial}

Na América do Norte e no norte da Europa, os judeus e os imigrantes da periferia europeia hoje são aceitos como "brancos" ou "europeus". O 
ritmo dessa transformação variou entre grupos e contextos. Em ambos os lados do Atlântico o antisemitismo ficou desacreditado depois do nazismo e do holocausto. Depois da guerra, vários grupos de migrantes da Irlanda e do sul ou leste da Europa também ganharam plena aceitação no norte europeu, como discutido acima. De fato, é somente no pós-guerra que podemos observar a gradual emergência de uma identidade europeia, em contraste com o resto do mundo. Agora, "branco" virou simplesmente sinônimo de europeu, em contraste com a hierarquia anterior, em que alguns europeus eram considerados mais brancos que outros. Não é por acaso que o pósguerra também foi a época da descolonização da Ásia e da África. Cada vez mais, as barreiras migratórias seriam direcionadas contra os não europeus.

O conhecimento da história das relações entre os antigos centros imperiais e as terras por eles colonizadas, conquistadas ou subordinadas é essencial para a compreensão dos fluxos migratórios internacionais de hoje. Como Stephen Castles diz,

Uma compreensão histórica das sociedades e das relações entre elas é crucial [para entender as migrações]. Por exemplo, nenhuma análise da migração para a Grã-Bretanha poderia ser completa sem uma compreensão da história do colonialismo e racismo britânicos; nenhuma análise da migração mexicana para os EUA poderia ser válida sem consideração da expansão histórica dos EUA e suas políticas de recrutamento de mão de obra no passado (Castles, 2010, p. 1573).

Entretanto, boa parte do debate público sobre a imigração a estes países procede como se os asiáticos e caribenhos no Reino Unido, ou os mexicanos nos Estados Unidos, fossem intrusos que invadiram a terra dos outros.

Boa parte da imigração das últimas décadas para a Europa e a América do Norte é o que muitas vezes se denomina "migração pós-colonial" de moradores dos países anteriormente sujeitos à dominação colonial, ou ainda de territórios em algum momento conquistados por impérios continentais. Em muitos casos, os migrantes vão para a antiga metrópole colonial, em função do conhecimento da língua, algumas facilidades ou preferências para os cidadãos das ex-colônias, ou ainda a presença de parentes já 
estabelecidos na metrópole durante a época colonial. Argelinos foram para a França, indianos, paquistaneses e caribenhos para o Reino Unido, Filipinos e cubanos para os Estados Unidos, indonésios e surinameses para a Holanda e latino-americanos para a Espanha. Em outros casos, os moradores de ex-colônias foram para outro país metropolitano, que não colonizou sua terra de origem diretamente, caso dos turcos na Alemanha, dos marroquinos na Holanda ou dos indianos nos Estados Unidos.

Ao tratar esses "novos imigrantes" como invasores estranhos e difíceis de assimilar, as ex-potências coloniais esquecem da história de sua própria presença não convidada nas terras de origem desses migrantes, e o fato de que a dominação colonial fortaleceu os vínculos entre colônias e metrópoles, ao mesmo tempo em que enfraqueceu os vínculos laterais entre os países colonizados. Durante a época mais intensa do surgimento dos nacionalismos europeus, entre o final do século XVIII e início do XX (Anderson, 1991), os principais países europeus eram impérios, não Estados-nações, e os integrantes dessas nações hoje esquecem do seu passado imperial, como se este não tivesse relação com a questão da imigração hoje (Cooper, 2005). Os primeiros imigrantes das colônias ou ex-colônias geralmente foram trazidos pelos colonialistas, primeiro como escravos ou curiosidades para a exibição, depois como recrutas militares para lutar nas duas guerras mundiais e finalmente como mão de obra para aliviar a falta de trabalhadores depois da Segunda Guerra. As elites das várias metrópoles achavam que os imigrantes voltariam aos seus países de origem quando seus serviços não fossem mais necessários, mas, em vez disso, eles lutaram por direitos, trouxeram suas famílias e estabeleceram comunidades permanentes (Lucassen et al., 2006).

\section{A amnésia colonial dos impérios continentais}

Mas podemos dizer mais. Com uma definição mais ampla de colonialismo, incluindo não somente os impérios de ultramar, mas também os impérios continentais, que se expandiram pela conquista das terras contíguas de outros povos, como os Estados Unidos, Canadá, Brasil, Rússia e Prússia, podemos 
entender muito sobre os fluxos migratórios recentes e as reações a eles. As terras conquistadas quase sempre já tinham moradores, que foram racializados, subordinados e, muitas vezes, massacrados. Vários dos impérios continentais também se originaram como colônias de assentamento europeias, que, por definição, tomaram as terras de outros povos, e cujas políticas posteriores de imigração muitas vezes discriminaram os não europeus.

Uma forma de amnésia imperial comum nos países de assentamento, como Estados Unidos, Canadá, Austrália e Argentina, é a ideia de que a população do país era originalmente branca, e que os outros, os não brancos, só apareceram recentemente - o que ignora a cor dos moradores originais desses países e as intervenções políticas do passado para impedir a imigração e a naturalização dos não europeus. Como a memória coletiva é um dos alicerces da identidade social, é preciso esquecer muito para manter a identidade de "países brancos" (Ernst, 2017; Pollak, 1992). Nos Estados Unidos, uma lei de 1790 limitou a naturalização a "brancos livres", sem definir quem podia ser considerado branco. Na prática, todos os europeus eram aceitos - mesmo contra a oposição popular e apesar de judeus europeus, irlandeses, latinos e eslavos não serem socialmente considerados brancos plenos - aparentemente porque o Estado priorizava o aumento da população do Oeste como maneira de acuar os indígenas e segurar esse vasto território contra as pretensões canadenses. Mais tarde, vários processos judiciais definiram, às vezes de maneira contraditória, quem era "branco", aceitando, por exemplo, armênios e alguns sírios, mas rejeitando japoneses e indianos. Os mexicanos conseguiram se naturalizar, em função de tratados dos Estados Unidos com México (FitzGerald; Cook-Martín, 2014). Entretanto, uma decisão da Corte Suprema, em 1857, explicitou que negros não podiam ser cidadãos, mesmo quando nascidos livres no país. Foi somente em 1866 que os negros ganharam o direito à cidadania, e a 14⿳⺈ emenda à constituição, de 1868, garantiu a cidadania a todos nascidos no país e sujeitos às suas leis, o que excluiu de cidadania os povos indígenas que moravam em reservas (Chambers, 2013). Tais indígenas só ganharam a cidadania nacional em 1924. 
A conquista do oeste dos Estados Unidos e do Canadá envolvia o deslocamento de grandes populações indígenas, a migração de mais de dez milhões de colonos, e, no início do século XX, a migração de mais de 2,5 milhões de mexicanos ao sudoeste dos Estados Unidos (McKeown, 2004). No Brasil, a cidadania plena é até hoje negada aos indígenas, ficando estes sujeitos à tutela do Estado, como se fossem menores ou incapazes. O povoamento do sul do Brasil por colonos brancos foi precedido por duas formas de limpeza étnica. Primeiro, os indígenas foram eliminados ou segregados em reservas. Depois, o Estado e as empresas de colonização expropriaram os caboclos, em muitos casos parcialmente descendentes de indígenas, que ocupavam as terras. Várias décadas depois, a ditadura militar favoreceria os colonos brancos do Sul para a ocupação das terras indígenas do norte do país.

Se incluirmos como "colonial" tudo que diz respeito à dominação da Europa e às "Novas Europas", ou colônias de assentamento, sobre o resto do mundo, também precisamos contar a migração forçada de milhões de cativos africanos para trabalhar como escravos na América como um dos grandes movimentos populacionais coloniais. Para poder pensar a imigração mais antiga como essencialmente de brancos, países americanos como os Estados Unidos, o Brasil e a Argentina precisam esquecer o tráfico de africanos escravizados. O esquecimento se estende também ao acúmulo de capital possibilitado pelo trabalho não remunerado de africanos e descendentes. Com esse duplo esquecimento, muitos brancos dos Estados Unidos e da Argentina tendem a pensar seus países como "países brancos", construídos pela força dos imigrantes europeus e descendentes. No caso do Brasil é mais difícil esquecer a presença de descendentes de africanos e de indígenas em um país onde pretos e pardos constituem um pouco mais da metade da população. Entretanto, no Brasil também há forte tendência de esquecer da contribuição dos negros à construção do país e ao acúmulo de capital, o que possibilita a crença comum de que somente os imigrantes europeus trouxeram o desenvolvimento e a industrialização.

As intervenções políticas para favorecer a população colonizadora - os brancos, na América - eram mais fortes, segundo FitzGerald e Cook-Martín 
(2014), onde os colonos tinham direitos democráticos. Eles usaram esses direitos para excluir os outros e manter seus monopólios das terras, dos empregos e do poder político. O exemplo mais evidente de tal tendência é a exclusão da imigração chinesa ao final do século XIX e início do XX dos Estados Unidos e do Canadá. Apesar de não sofrer a colonização formal, a China sofreu forte pressão e interferência imperial da Inglaterra ao longo do século XIX. Na mesma época em que milhões de europeus migraram para a América, milhões de chineses também migraram para outras regiões da Ásia. Milhares de chineses também foram para a América como trabalhadores contratados ou como migrantes espontâneos.

Os Estados Unidos lideraram o movimento pela exclusão dos chineses e de outros asiáticos. Com a grande imigração de chineses para trabalhar na agricultura da Califórnia e de outros estados do Oeste, e para a construção das ferrovias, os trabalhadores brancos organizados em sindicatos começaram a pressionar pela exclusão dos chineses. Houve até distúrbios antichineses em San Francisco (Hoerder 2002, p. 399). Com a ascendência social de alguns chineses, japoneses e outros asiáticos com pequenos negócios, uma parte da classe média branca também receava a competição dos imigrantes e se juntou às organizações apelando pela exclusão. Finalmente, intelectuais e elites políticas apoiaram o fim da imigração chinesa e a proibição da naturalização dos chineses já presentes no país, com o argumento de que eram inassimiláveis e despreparados para o autogoverno democrático. Várias leis da segunda metade do século XIX proibiram a imigração de trabalhadores chineses e proibiram a naturalização dos chineses já presentes no país (FitzGerald; Cook-Martín 2014, p. 90-6). Essas leis só foram revogadas em 1943. Como resultado dessa exclusão política, a migração chinesa para a América caiu de 20 a 35\% de toda a emigração chinesa no período entre 1850 e o início da década de 1870, para 2 a 5\%, depois de 1890, justamente quando havia um grande aumento na emigração da Ásia (McKeown, 2004). Ou seja, esta intervenção política assegurou a continuidade da predominância de brancos nos estados da costa do Pacífico dos Estados Unidos, limitando drasticamente o crescimento da proporção de pessoas de origem asiática. 
Com a exclusão da imigração chinesa aos Estados Unidos, os trabalhadores, classe média e elites do Canadá, com medo de que a corrente migratória se desviasse para seu país, mobilizaram-se com sucesso pela exclusão dos chineses também do Canadá (FitzGerald; Cook-Martín, 2014, p. 146-56). O Brasil da República Velha era pouco democrático, e os trabalhadores tiveram pouca influência nas políticas de imigração, mas propostas de fazendeiros para a importação de trabalhadores chineses não prosperaram, em boa parte porque a elite política nacional pensava os chineses como "degenerados" e inassimiláveis, o que complicaria a tarefa da construção de uma nação brasileira (FitzGerald; Cook-Martín, 2014, p. 267-8; Lesser 1999; Skidmore 1993). Além do mais, com a disponibilidade de grande número de potenciais imigrantes italianos, espanhóis e portugueses nessa época, as elites brasileiras não precisavam de trabalhadores chineses.

Em todos esses países, o Japão, que escapou da dominação pelos países imperialistas, conseguiu negociar tratamento um pouco melhor para seus emigrados. Os Estados Unidos e o Canadá negociaram diretamente com o governo do Japão para limitar a imigração japonesa, sem a humilhação internacional de uma proibição parecida àquela imposta aos chineses. Com o patrocínio do governo do Japão, várias colônias de japoneses foram estabelecidas no Brasil no início do século XX, especialmente no estado de São Paulo (Sakurai, 1999).

\section{A divisão dos territórios e a criação dos "imigrantes ilegais"}

As conquistas territoriais dos impérios continentais muitas vezes dividiram arbitrariamente regiões que antes eram politicamente unificadas, ou onde os moradores podiam transitar livremente. Ao final do século XVIII, os impérios da Prússia, da Rússia e da Áustria dividiram a Polônia. Na primeira metade do século XIX, os Estados Unidos conquistaram boa parte do México e dividiram este país. O Brasil e o Paraguai dividiram o território dos Guaranis, como o Brasil e outros países vizinhos também dividiram os territórios de outros grupos indígenas. Na fronteira entre 
os Estados Unidos e Canadá, vários grupos indígenas sofreram a divisão arbitrária dos seus territórios.

A formação desses impérios continentais teve duas consequências para os migrantes. Primeiro, pessoas que antes podiam se movimentar livremente dentro do território de sua nação, de repente foram redefinidas como imigrantes, ou até como intrusos ilegais, quando atravessavam a nova fronteira imposta pelo império conquistador. $\mathrm{O}$ ato de migrar agora significava a perda dos direitos de cidadania e, com o passar do tempo, a sujeição a um aparato crescente de controles burocráticos e policiais (Herbert, 2001; Reinecke, 2009; Volpp, 2005). A segunda é que as conquistas resultaram em populações de "estrangeiros" dentro desses impérios, as quais viraram cidadãos de segunda classe, cuja cidadania podia ser questionada ou revogada, e que estavam permanentemente vulneráveis a maus tratos, à assimilação forçada ou até à deportação.

\section{Os mexicanos e descendentes nos Estados Unidos}

Até 1919, os mexicanos podiam entrar nos Estados Unidos livremente, em função da necessidade de seu trabalho na agricultura. Depois dessa data, precisavam solicitar a entrada e pagar taxas em locais designados. Aqueles que não cumpriam esses requisitos viraram "imigrantes ilegais". Com a intensificação das deportações de imigrantes em situação irregular, os europeus que entraram ou ficaram ilegalmente ganharam isenções e tratamento preferencial a partir da década de 1930, permitindo que muitos se legalizassem depois de uma breve passagem pelo Canadá, onde obtiveram visto de um consulado estadunidense. Chineses e mexicanos foram impedidos de se legalizar por esse procedimento. No início da década de 1930, durante a grande depressão, mais de 400.000 "mexicanos" do sudoeste e do meio-oeste do país, boa parte deles cidadãos dos Estados Unidos por nascimento, foram "repatriados" para o México. Assim, na mesma época em que o governo dos Estados Unidos facilitava a entrada ilegal de europeus, deportava cidadãos do próprio país cujos pais ou avós eram mexicanos, o que não somente alterou a composição da população 
em muitos locais, mas também ajudou a consolidar a representação legal do branco como cidadão e do mexicano como estrangeiro permanente (Volpp, 2005; Waters; Kasinitz 2015).

Entretanto, agricultores enfrentavam a falta de mão de obra a partir do final da década de 1930 e insistiam na necessidade de importar trabalhadores com contratos temporários, que aceitavam salários menores que os brancos nativos. Entre 1942 e 1964, o Bracero Program trouxe aproximadamente 4,6 milhões de mexicanos, que fizeram uma contribuição essencial à manutenção da economia do país durante os anos da guerra. Um programa menor, o British West Indies Temporary Alien Labor Program, levou trabalhadores de Jamaica, Barbados e Santa Lucia para a colheita de maçãs no nordeste dos Estados Unidos e a colheita de cana na Flórida, ente 1943 e 1977. Tais programas tratavam os migrantes como mão de obra e tentavam impedir seu estabelecimento permanente no país (Hyland, 2017; Volpp, 2005).

Oficialmente, a política de imigração dos Estados Unidos, desde 1965, não discrimina por origem, cor, religião, aparentemente porque o sistema discriminatório anterior estava prejudicando as relações do país com a Ásia e a África. O sistema de cotas foi modificado para um limite de 20.000 por país por ano do Hemisfério Leste e um máximo total desse hemisfério de 170.000, com exceção dos parentes imediatos (cônjuges, filhos ou pais) de cidadãos dos Estados Unidos. A partir de 1968, a lei limitou o número de imigrantes das Américas a 120.000 por ano, e uma nova lei de 1976 impôs o limite de 20.000 por país também ao Hemisfério Oeste. Os limites mundial e por país foram aumentados em 1990, mas o sistema continuou com a mesma lógica (FitzGerald; Cook-Martín, 2014, p. 117-23, 129). Embora se aplique de forma igual a todos os países, o limite é uma boa maneira de impedir a imigração legal de mexicanos, porque o número de pessoas querendo migrar do México aos Estados Unidos é muito maior que o número de imigrantes potenciais de qualquer outro país. Com a limitação severa da cota para mexicanos, multiplicou-se o número de "imigrantes ilegais", porque a grande maioria daqueles que anteriormente podiam imigrar legalmente de repente passou a enfrentar barreiras insuperáveis ou décadas de espera para a permissão oficial. 
O sistema também mantém certo fluxo de europeus e outros brancos, ao mesmo tempo em que aumenta o número de imigrantes da Ásia, da África e dos outros países da América (Chishti et al., 2015; Waters; Kasinitz, 2015).

Com o aumento do número de "mexicanos ilegais" nos últimos 50 anos, as representações desses migrantes foram mudando. Anteriormente retratados como preguiçosos e maconheiros - representações que provavelmente se originaram entre os fazendeiros e outros empregadores - agora viraram "ladrões de empregos", "criminosos" e "aproveitadores de serviços públicos". Esta última acusação diz respeito especialmente às escolas, porque as taxas de fertilidade das mexicanas são relativamente altas. De maneira geral, as novas representações são falsas - os mexicanos fazem trabalho rejeitado pelos nativos e estimulam a economia; as taxas de criminalidade entre os mexicanos (e quase todos os grupos imigrantes) são mais baixas do que aquelas entre os nativos; os mexicanos também pagam bem mais em impostos do que recebem em serviços, e o trabalho dos seus filhos nascidos no país, que são cidadãos, será necessário no futuro para a amenizar a crise do sistema de seguridade social causada pelo envelhecimento da população. Entretanto, políticos oportunistas promovem tais representações negativas porque, sem assumir o racismo abertamente, querem ganhar votos fomentando o medo de uma "invasão" de multidões de mexicanos, o que poderia resultar, além dos supostos problemas mencionados acima, na perda do controle político por brancos em muitas localidades. Esta estratégia política se evidencia na demonização atual da Califórnia, o primeiro estado dos Estados Unidos continental em que os brancos constituem uma minoria, pelo presidente Trump e pelo Partido Republicano.

\section{Os poloneses e descendentes na Prússia/Alemanha}

A relação histórica da Alemanha com a Polônia é análoga, em vários aspectos, à relação dos Estados Unidos com o México. O território da Prússia se expandiu por conquistas militares, casamentos reais estratégicos e a divisão da Polônia entre Prússia, Rússia e Áustria. No século XVIII, a monarquia prussiana convidou um grande número de imigrantes protestantes, com preponderância daqueles de fala alemã, para colonizar o leste do território, e imigrantes e seus 
filhos chegaram a constituir quase $20 \%$ da população da Prússia (Hoerder, 2002). Assim, a monarquia usou uma estratégia demográfica que era simultaneamente religiosa e étnica para ocupar e defender os territórios conquistados.

Depois da unificação da Alemanha, em 1871, houve uma grande migração de poloneses para a região de mineração e industrial do Ruhr, ao final do século XIX e início do XX. Muitos deles já eram oficialmente cidadãos da Alemanha, porque provinham de partes da Polônia incorporadas à Prússia, embora se identificassem como poloneses e fossem tratados como estrangeiros pelos alemães da região receptora. Na mesma época, milhares de poloneses das regiões controladas pela Rússia e pela Áustria foram recrutados para trabalhar na agricultura do leste da Alemanha. Considerando os eslavos como povos inferiores, o governo desenvolveu o sistema de controle de migrantes mais elaborado da época para impedir a permanência dos poloneses em território alemão. Em 1885, motivado por hostilidade aos católicos e ao movimento independentista dos poloneses, expulsou 40.000 "poloneses estrangeiros", inclusive mulheres alemãs que haviam se casado com poloneses. Em resposta aos pedidos de empregadores, o governo novamente permitiria a entrada de poloneses e outros do Leste a partir de 1890, mas os sujeitou a um regime rigoroso de controle estatal. Somente solteiros podiam participar, e eram obrigados a deixar o território alemão todos os invernos. A Alemanha logo se transformou no segundo maior importador de trabalhadores do mundo. Além dos poloneses, chegou um número relativamente grande de italianos e números menores de outras nacionalidades, totalizando 1,26 milhão de trabalhadores imigrantes até 1910 , incluindo mais de meio milhão de mulheres (Hoerder, 2002; Herbert, 2001; Reinecke, 2009).

A Alemanha imperial também tentou forçar a assimilação das centenas de milhares de poloneses étnicos com cidadania alemã que trabalhavam na região do Ruhr, mas os poloneses reagiram com o fortalecimento das associações e jornais étnicos, e até formaram um sindicato de trabalhadores poloneses (Hoerder, 2002; Lucassen, 2006). Depois do tratado de paz de Versailles e o reestabelecimento do Estado polonês, os poloneses étnicos da região do Ruhr tinham de escolher entre a cidadania polonesa ou alemã, e 
somente uma minoria escolheu a cidadania polonesa e voltou àquele país. Em contraste, um número muito maior, talvez uns 300.000 no total, migrou para os distritos industriais do norte da França durante a crise econômica dos anos 1920. Somente um terço dos poloneses continuaram na região do Ruhr (Schönwalder, 2006).

Nos anos de 1930, os nazistas simplesmente fecharam todas as organizações étnicas dos poloneses na Alemanha, prendendo ou matando seus líderes. Hoje essa história dolorosa de assimilação forçada é esquecida, e os descendentes de poloneses na região do Ruhr perderam a identidade étnica, sendo vistos por muitos na Alemanha como um exemplo de integração bem-sucedida, em contraste com os turcos que migraram para a mesma região a partir do início da década de 1960 (Lucassen, 2006; Peters-Schildgen, 2003; Pöttger, 2015; Reinecke, 2009).

Os nazistas também radicalizaram a estratégia de conquista e colonização dos territórios eslavos com uma guerra de extermínio contra os poloneses e russos (Oltmer, 2006). O plano era transferir a fronteira da Alemanha pré-guerra - que já ocupava boa parte da atual Polônia $500 \mathrm{~km}$ para o leste, eliminar ou expulsar os eslavos e ocupar o "novo" território com alemães, especialmente os alemães étnicos do sul e do leste da Europa. Os nazistas pretendiam expulsar ou exterminar entre $80 \%$ e $85 \%$ dos poloneses, $75 \%$ dos bielorrussos, $65 \%$ dos ucranianos e $50 \%$ dos tchecos, mantendo, em uma região além da nova fronteira, uma grande população dos eslavos "sub-humanos" para servir como reserva de mão de obra barata (Hoerder, 2002). Entretanto, a expulsão dos eslavos dos territórios conquistados era só parcialmente viável, porque havia severa falta de mão de obra na Alemanha durante a guerra. Até 1944, mais de 7,6 milhões de estrangeiros trabalhavam na Alemanha, boa parte deles poloneses e russos escravizados, inclusive muitos judeus, antes destes serem enviados aos campos de extermínio (Herbert, 2001).

O fato de os nazistas terem perdido a guerra e os territórios conquistados no Leste levou a um grande refluxo de alemães desses territórios à Alemanha logo depois da guerra. Um grande número de alemães étnicos 
também chegou à Alemanha vindos de outros países do Leste, onde eram considerados colaboradores dos nazistas e expulsos ou discriminados. Ainda outra grande migração de alemães étnicos chegou à Alemanha a partir dos países do Leste depois do fim dos regimes comunistas e a abertura das fronteiras (Dietz, 2006).

Hoje, os poloneses constituem o grupo de imigrantes mais numeroso na Alemanha, mas raramente são referidos como problemáticos, ao contrário da situação de um século atrás. Um grande número de poloneses migra para trabalho sazonal na agricultura alemã, e estima-se que entre 150.000 e 300.000 mulheres do Leste trabalham como empregadas domésticas ou cuidadoras de idosos na Alemanha (Hoock, 2016). Os alemães, de maneira geral, reconhecem que o trabalho de poloneses é uma contribuição importante à economia do país, porque a grande maioria dos alemães não quer esses empregos. Em alguns casos, os poloneses são referidos como "bons imigrantes" ou "mais assimiláveis", geralmente em contraste com os turcos e os refugiados sírios, que chegaram em grandes números nos últimos anos.

Por que os migrantes mexicanos nos Estados Unidos suscitam tanta polêmica, enquanto os poloneses na Alemanha são aceitos com tranquilidade? A explicação não pode ter a ver com a religião, porque em ambos os países, hoje, há pouca hostilidade de protestantes contra católicos. Tampouco é convincente atribuir a diferença à branquitude dos poloneses, pois eles sofreram forte racialização no passado alemão, sendo definidos como racialmente inferiores e indesejáveis, tanto pelo governo imperial como pelos nazistas.

Uma diferença importante entre os dois países é que os Estados Unidos nunca reconheceram honestamente seu passado racista da mesma maneira que a Alemanha reconheceu o passado nazista, a partir do confronto geracional da década de 1960 (Elias, 1997). A rejeição do racismo do passado e, especialmente, do nazismo e dos crimes dos nazistas contra outros povos certamente coíbe tendências para a reação contra a presença polonesa. Entretanto, o reconhecimento do racismo do passado não impede a reação contra imigrantes muçulmanos por uma parte da população alemã. 
Também há outras diferenças salientes entre a Alemanha e os Estados Unidos. Em contraste com os migrantes mexicanos nos Estados Unidos, os poloneses que trabalham na Alemanha são migrantes legais, devido às leis da União Europeia, e geralmente não pretendem ficar permanentemente. Por outro lado, os perigos crescentes de atravessar a fronteira levaram muitos homens mexicanos, que antes mantinham casa e família no México e circulavam entre os dois países, a trazer suas famílias aos Estados Unidos e lá permanecerem. Além disso, a lei alemã dificulta a naturalização e não dá a cidadania automaticamente aos filhos de estrangeiros nascidos no país. Com isso, políticos oportunistas não conseguem fomentar medo de que os poloneses vão mudar a composição demográfica e cultural da Alemanha e ganhar o poder político. Alguns políticos do partido da extrema direita anti-imigrante Alternative für Deutschland (AfD) culpam "quadrilhas do leste europeu" por arrombamentos de casas e furtos de carros e bicicletas, mas o apelo deste partido se baseia muito mais na sua oposição à imigração de muçulmanos e à suposta "islamização da Europa".

\section{A amnésia e a reação às migrações "pós-coloniais"}

$\mathrm{Na}$ esteira da segunda guerra, para resolver a falta de mão de obra, vários países incentivaram a imigração de "trabalhadores-hóspedes", alguns deles europeus, outros não - por exemplo, italianos na Suíça, na Alemanha e na Holanda, argelinos na França, turcos na Alemanha e na Holanda, marroquinos na Holanda. Os fluxos tinham muito a ver com laços coloniais e linguísticos, com proximidade geográfica ou com convênios entre governos dos países de emigração e imigração. Em alguns casos, como o Reino Unido e a França, os habitantes das colônias tinham o direito à mobilidade dentro do espaço imperial. A Alemanha havia perdido suas colônias de ultramar depois da Primeira Guerra, e perdeu o acesso à mão de obra polonesa com a instalação do regime comunista nesse país, mas fechou acordos para o recrutamento de trabalhadores com alguns países do sul da Europa e com a Turquia, no final da década de 1950 e início da década de 1960. Boa parte 
da primeira grande leva de turcos foi para as minas de carvão e a indústria do Vale do Ruhr.

Por serem trabalhadores, esses "hóspedes" ganharam direitos sociais, e muitos acabaram trazendo a família e ficando. Quando ficou evidente que não voltariam para os países de origem, desencadearam-se discussões sobre os problemas de integração e o direito à cidadania dos descendentes nascidos no país de destino. Na França e no Reino Unido, os filhos de imigrantes nascidos no país tinham o direito à cidadania, mas a Alemanha dificultava a naturalização e não concedeu a cidadania automaticamente às pessoas nascidas no país, produzindo uma minoria permanente sem direitos de cidadania, ao mesmo tempo em que muitos alemães reclamavam que os turcos eram "inassimiláveis". Só a partir da reforma de 1999 é que os filhos de turcos e de outros imigrantes tiveram o direito de optar pela cidadania alemã antes de completar 23 anos. Essa reforma ainda é debatida na Alemanha, onde muitos acham que somente descendentes de alemães devem ter o direito à cidadania, esquecendo da transformação dos imigrantes europeus do passado em "alemães de sangue".

No Reino Unido, a reação contra a imigração focalizou principalmente os imigrantes não brancos do ex-império britânico, especialmente indianos, paquistaneses e caribenhos, todos referidos no contexto britânico como "blacks", ou negros. Na França, concentrou-se principalmente nos argelinos e outros do norte da África. Na Alemanha, os turcos eram apontados como mais problemáticos e menos integráveis que os imigrantes do sul da Europa. O debate público sobre essas questões é quase sempre enquadrado em termos culturais, e não explicitamente "raciais", embora possamos dizer que há uma racialização da cultura na Europa. Os imigrantes não europeus são retratados como inassimiláveis. A religião islâmica, especialmente, é muitas vezes discutida como se fosse intrinsicamente inferior e imutável, condenando os fiéis para sempre ao fanatismo, à intolerância e a atitudes 
machistas. ${ }^{2}$ Por isso, o grau de preconceito étnico e racial dos brancos europeus não se correlaciona, necessariamente, à cor da pele dos imigrantes. Em vários países da Europa hoje, o preconceito ou racismo de cunho religioso contra muçulmanos é mais forte que o racismo contra negros (Pries; Bekassow 2015). Na França, os argelinos geralmente são vistos como mais problemáticos do que os africanos do sul do Saara (Blanc-Chaléard, 2006). Na Holanda, os marroquinos sofrem estigmatização mais forte do que os surinameses negros, que falam holandês e geralmente não são muçulmanos (Lucassen; Lucassen, 2015).

A reação contra a imigração pós-colonial levou as ex-metrópoles a cancelarem ou restringirem os direitos de movimento dos ex-colonizados dentro do espaço imperial. A partir do início da década de 1960, o Reino Unido cancelou o direito de residência dos imigrantes das colônias e começou a dificultar a imigração desses países. A França limitou a partir de 1974 a imigração de argelinos e outros do norte da África.

Muitos dos estereótipos desses "novos imigrantes" se originaram na época colonial, entre os administradores, colonos e cientistas que para lá se dirigiram com o intuito de administrar, explorar, pilhar ou estudar os colonizados. Tais estereótipos se espalhavam nos centros imperiais na forma de obras literárias e relatos de viagens (Hoerder, 2002). Pelo esquecimento de seus passados imperiais, os europeus e os norte-americanos de hoje reproduzem os estereótipos coloniais como se fossem observações objetivas dos imigrantes. Este processo é particularmente evidente com respeito aos imigrantes muçulmanos.

O preconceito contra os muçulmanos já existia antes do colonialismo europeu, mas foi ampliado pelo colonialismo. Como salientado por Edward Said (1978) e muitos autores posteriores, o mundo islâmico foi, durante séculos, o principal inimigo da Europa cristã e o contraste com

2 Além da reação contra muçulmanos, que é geral na Europa, o Reino Unido destoa do continente pela força da reação contra a imigração dos poloneses. Nos anos recentes, houve uma onda de violência contra poloneses na Inglaterra e a ideia de que "os poloneses roubam nossos empregos" pode explicar boa parte do voto pelo Brexit, que eliminará o direito dos europeus continentais de morarem e trabalharem no Reino Unido (Monsma, 2017). 
esse "outro" foi fundamental na formação da identidade europeia. A dominação colonial dos países islâmicos da África, do Oriente Médio e da Ásia reforçou estereótipos dos muçulmanos como exóticos e sensuais, por um lado, e fanáticos violentos, por outro (Docter, 2011; Lee, 2011; Machaqueiro, 2012). Quando pequenos grupos de muçulmanos extremistas realizam atentados no Ocidente, o discurso predominante na mídia e nos governos ocidentais generaliza o velho estereótipo de fanatismo a todos os muçulmanos, tratados como atrasados, despreparados para a convivência democrática e terroristas em potencial (Poynting; Mason, 2007; Saeed, 2007; Said; Jhally, 2005.). Em contraste, os atentados terroristas realizados por católicos da Irlanda do Norte, por bascos independentistas, ou por supremacistas brancos estadunidenses não resultaram na estigmatização de todos os irlandeses católicos, de todos os bascos ou de todos os brancos como fanáticos perigosos e despreparados para a cidadania democrática.

No caso específico da Inglaterra, também há amnésia a respeito de toda a longa história de dominação colonial da Irlanda e da racialização dos irlandeses (Miles, 1993), que hoje são classificados entre os "bons" imigrantes "brancos". Tal como no continente e na América do Norte, muitos ingleses aceitam o estereótipo do "muçulmano terrorista", esquecendo de que, até recentemente, a maioria dos atentados terroristas na Inglaterra eram cometidos pelo Irish Republican Army (IRA), que lutava contra a dominação da Inglaterra e dos protestantes na Irlanda do Norte, ou Ulster.

As representações negativas dos ex-colonizados talvez sejam mais fortes nas metrópoles que estabeleceram colônias de assentamento e receberam grande número de retornados dessas colônias depois da sua independência. Os colonos franceses na Argélia, muitos dos quais voltaram para a França ressabiados depois da independência argelina, interferiram diretamente no desenvolvimento de estereótipos a respeito dos argelinos (Blanc-Chaléard, 2006). As particularidades de cada caso devem ser estudadas, mas parece que os estereótipos negativos dos imigrantes das ex-colônias podem ser menos fortes nos casos em que as ex-colônias ganharam a independência sem guerra e pouco brancos retornaram às metrópoles. 
No caso da Alemanha, o país esqueceu-se quase por completo do fato de ter sido uma potência colonial na África e no Pacífico por quase 30 anos antes do fim da Primeira Guerra Mundial. Os oriundos das ex-colônias alemãs não ganharam nenhuma facilidade para a imigração. Entretanto, o exemplo do estereótipo do muçulmano fanático e inassimilável também se difundiu na Alemanha, mostrando que tais representações facilmente se espalham para outros países que recebem imigrantes das mesmas origens.

Uma forma de islamofobia mais recente alega que imigrantes muçulmanos ameaçam as conquistas das mulheres, dos homossexuais e de outras minorias sexuais. Esta vertente talvez seja mais forte na Holanda, país com forte autoimagem progressista e tolerante, onde Pim Fortuyn, o primeiro político antimuçulmano a ganhar destaque, era abertamente gay. Depois do assassinato de Fortuyn por um islamista, o novo líder das forças anti-imigrantistas, Geert Wilders, é heterossexual, mas enfatiza a ameaça dos imigrantes muçulmanos à igualdade de direitos para homossexuais (Lucassen; Lucassen 2015). Na Alemanha, Alice Weidel, colíder do partido anti-imigrantista de extrema direita Alternative für Deutschland (AfD), é abertamente lésbica, e sua companheira é uma suíça de origem srilankesa. Entretanto, a união homossexual com uma imigrante não branca parece não incomodar os outros do partido, cuja ênfase central é impedir a imigração e influência islâmicas. Tais políticos aproveitam o medo de que a presença islâmica na Europa acabará revertendo os ganhos dos LGBTQ. De maneira geral, alegam que os muçulmanos constituem uma ameaça à tolerância europeia e que são incapazes de se integrar na Europa. Além de generalizar a todos os muçulmanos o fanatismo de uma pequena minoria, estes políticos e seus seguidores esquecem da história de intolerância e violência dos seus próprios países, tanto dentro da Europa como nas colônias, representando os países europeus como essencialmente progressistas, democráticos e tolerantes, em contraste com o fanatismo e o atraso "medieval" dos ex-colonizados.

$\mathrm{Na}$ Europa atual, os movimentos anti-imigrantistas tendem a ser mais fortes nos países do Leste, onde há poucos imigrantes de fora da UE. Em alguns casos, como a Hungria e a Polônia, nacionalistas anti-imigrantistas 
ganharam a presidência e fomentam ainda mais esse tipo de sentimento. Na Alemanha, a base mais forte de apoio ao Alternative für Deutschland (AfD), o partido da extrema direita anti-imigrante, é na antiga Deutsche Demokratische Republik (DDR), a Alemanha comunista. Em Dresden, onde o movimento anti-islamico Pegida começou, quase não há muçulmanos.

O que explicaria essa movimentação contra imigrantes, especialmente contra muçulmanos, em países e regiões onde há poucos imigrantes? Os países do Leste sofreram a longa dominação pela Europa Ocidental, culminando na violência nazista. Posteriormente, passaram várias décadas de dominação pela União Soviética. Esta região só recentemente ingressou na União Europeia, depende de subvenções dos países mais ricos e serve como reserva de mão de obra barata para os países ocidentais. Muitos dos seus cidadãos, portanto, podem não se sentir plenamente aceitos como europeus e proclamam seu pertencimento à "Europa cristã" pela rejeição dos migrantes de fora desse espaço, sobretudo dos muçulmanos, ao mesmo tempo em que afirmam sua soberania nacional pela rejeição da dominação pela Alemanha e das quotas para refugiados impostas pela UE.

\section{A institucionalização do esquecimento}

As representações dos países que habitam como essencialmente "brancos", como nações que sempre existiam de forma independente das suas colônias e conquistas territoriais, e da imigração passada de europeus como pouco problemática são incorporadas ao habitus nacional dos cidadãos brancos dos países centrais. Entretanto este habitus não é produzido e reproduzido somente nas cabeças de indivíduos ou nas histórias familiares. Também é produto de instituições da memória coletiva, cultural e pública (Assmann; Czaplicka, 1995).

As instituições e os lugares da memória social incluem, entre outras coisas, a historiografia, os livros escolares, os monumentos públicos, os museus, os romances e filmes, e as obras de arte, além dos arquivos, que conservam vestígios selecionados do passado (De Certeau 1975; Nora, 
1993; Olick; Robbins, 1998). A memória social é necessariamente seletiva, o que implica que as instituições da memória também funcionam como instituições de esquecimento (Meneses, 1992), motivadas pela "formidável vontade de ignorar que se faz passar por saber" (Mbembe, 2014, p. 125). A amnésia social a respeito de eventos significativos do passado distorce nossa compreensão de processos sociais no passado e no presente (Clarke, 2012). Quando é impossível ignorar eventos que contradizem as identidades e narrativas coletivas predominantes, versões diluídas ou higienizadas de tais eventos podem permitir sua comemoração sem a subversão da memória predominante (Vinitzky-Seroussi; Teeger, 2010).

Durante muito tempo, na Europa e nos países de assentamento europeu, os lugares e instituições da memória naturalizavam as diferenças "raciais", apresentando a prosperidade e democracia desses países como manifestações da superioridade racial (Mbembe, 2014). Ao longo do século XIX, as diferenças raciais parecem ter substituído a divina providência nos relatos predominantes como principal influência no destino das nações. Hoje, as afirmações abertamente racistas geralmente desapareceram das instituições da memória desses países, mas perduram no pensamento e no habitus populares, e nas entrelinhas das afirmações, mais ou menos veladas, da superioridade cultural e moral - por exemplo, na glorificação da ética protestante, da tradição do "inglês nascido livre", do "humanismo latino" ou da ajuda humanitária ou desenvolvimentista que esses países concedem ao resto do mundo. Ao mesmo tempo, o resto do mundo é representado como desprovido de história própria, permeado por despotismo, corrupção, clientelismo, fanatismo, machismo, ignorância e violência. Em suma, o europeu e seus descendentes continuam se pensando como civilizados e os outros como incivilizados.

Esta memória pública racista se combina com a representação dos estados-nação como unidades naturais, desvinculadas das suas colônias. Há forte tendência de projetar os estados-nação de hoje ao passado, contando de modo anacrônico a história do Reino Unido, da França, da Espanha, dos Estados Unidos ou do Brasil, como se sempre tivessem sido nações com as 
mesmas fronteiras territoriais e culturais, desconsiderando o fato de que, mesmo na Europa, as nações atuais só se formaram nos últimos séculos (Tilly, 1996) e que os principais Estados da Europa foram impérios, não estados-nação, em alguns casos até meados do século XX, e que exibem traços imperiais até hoje (Cooper, 2005). Nas "biografias" das nações, há uma seleção dos eventos do passado que são coerentes com o presente, como se elas fossem predestinadas à sua forma e natureza de hoje. ${ }^{3}$ Como Benedict Anderson (1991, p. 199-200) demonstra, também há uma forte tendência para a posterior redefinição, como "fratricidas" ou "internas", dos conflitos do passado entre grupos sem identidades coletivas em comum, somente porque tais conflitos aconteceram dentro do território das nações atuais.

O esquecimento é particularmente evidente com respeito à história imperial. Gerações de crianças aprendem sobre a história de unidades chamadas "Inglaterra" ou "França" desconectada da história da Índia, da África ou do Caribe, o que reforça a autoimagem da Inglaterra como berço dos direitos do cidadão e da democracia parlamentar, e da França como terra da razão e da liberdade, igualdade e fraternidade. Os relatos da Revolução Francesa, por exemplo, geralmente nem mencionam a Revolução do Haiti e a tentativa de Napoleão de reimpor a escravidão na ex-colônia (Go, 2013). As histórias do Reino Unido geralmente põem pouca ou nenhuma ênfase na repressão brutal das rebeliões contra a dominação inglesa da Irlanda, da Índia ou do Quênia. As histórias da Holanda reforçam a autoimagem de um pequeno país progressista e tolerante, que doa milhões para subvencionar o desenvolvimento de países pobres, sem contemplar as implicações da atuação holandesa no tráfico de africanos escravizados nem da dominação imperial da Indonésia, de parte do Caribe e, de forma mais transitória, de outras partes da América, como os territórios das atuais Nova York e Pernambuco (Weiner, 2015).

As histórias dos impérios continentais tendem a tratar os territórios conquistados como lugares sem história antes de sua incorporação

${ }^{3}$ Neste aspecto, as histórias das nações se assemelham às biografias individuais criticadas por Bourdieu (2002). 
ao império. Isso é particularmente evidente no caso da conquista de aproximadamente metade do território mexicano pelos Estados Unidos em meados do século XIX. Na ideologia de "destino manifesto", predominante nos Estados Unidos da época, o país era naturalmente destinado a ocupar todo o território do Atlântico ao Pacífico, o que implicava que os povos já presentes eram ocupantes ilegítimos. Nos livros escolares, há alguma menção das missões franciscanas na Califórnia e dos conflitos com os povos indígenas, tratados como "culturas" estáticas, sem história (Wolf, 1982), mas esse enorme espaço geralmente não é tratado como parte da colônia espanhola de Nova Espanha, e depois parte da nação mexicana, com uma longa história anterior à conquista pelos Estados Unidos. Esta ausência faz uma diferença para a representação predominante hoje nos Estados Unidos dos mexicanos como intrusos "ilegais", e não como um povo que migra dentro do seu próprio território, que ficou dividido entre dois Estados. No Brasil, os povos indígenas são tratados muitas vezes como os "primeiros brasileiros" e não como nações independentes que foram conquistadas pelo Brasil/Portugal. Na Argentina, o genocídio dos povos indígenas do Sul na segunda metade do século XIX é referido até hoje como a "conquista do deserto", como se esse território fosse desabitado. O termo recente canadense, "primeiras nações", reconhece simbolicamente a anterioridade das nações indígenas, embora essas nações só tenham autonomia política limitada e muitos indígenas vivam em condições de miséria.

A Alemanha constitui uma exceção parcial a essa negação da história da conquista dos impérios continentais, porque é impossível negar as relações entre o projeto expansionista imperial e os crimes de guerra dos nazistas na frente leste, e boa parte da história pública da Alemanha hoje é orientada para lembrar os alemães da sua responsabilidade pelos crimes nazistas. Entretanto, o foco no período nazista tende a esconder as continuidades com o expansionismo da Prússia e do Império Alemão, permitindo a representação dos poloneses como estrangeiros, não como povo em vários períodos sujeito ao domínio do Estado prussiano ou alemão. O foco quase exclusivo nos crimes nazistas, apresentados como o cúmulo 
do mal, também desvia a atenção do fato de que a Alemanha possuía um grande império na África e no Pacífico nos 30 anos antes do fim da Primeira Guerra Mundial, e de que a Alemanha realizou outro genocídio antes do holocausto, o dos Herero e Nama da atual Namíbia (Steinmetz, 2007). Hoje há um número crescente de negros moradores ou cidadãos da Alemanha, mas eles ainda são vistos por boa parte da população como alienígenas, que não têm nada a ver com a história do país.

Em todos os casos mencionados acima, e com a exceção da representação dos nazistas na Alemanha, a ausência de uma abordagem séria aos crimes dos colonizadores, no ensino da história e na memória pública apresentada em museus e monumentos, permite a continuidade de mitos populares a respeito das relações entre os países "civilizados" e "atrasados", segundo os quais os povos colonizados se beneficiavam da tecnologia, educação e instituições modernas implantadas pelos colonizadores ("os ingleses levaram as ferrovias e a democracia à Índia"), e as migrações recentes das ex-colônias para as antigas metrópoles são vistas como prova da superioridade destes. Nos impérios continentais, alega-se que a conquista por uma "nação mais avançada" teria beneficiado os povos conquistados. No caso do oeste dos Estados Unidos, por exemplo, alega-se que os descendentes dos mexicanos conquistados gozam de um padrão de vida melhor do que teriam se tivessem continuado como cidadãos mexicanos. A "prova" disso seria o fato de que muitos mexicanos querem migrar para os Estados Unidos. ${ }^{4}$

\section{Conclusão}

O esquecimento do passado colonial e do passado da imigração é conveniente e necessário para a construção da memória da "velha" imigração como pouco problemática, composta quase exclusivamente de "brancos", e a construção da Europa Ocidental e de alguns países da América, principalmente os Estados Unidos, Canadá e Argentina como países

${ }^{4}$ Este tipo de argumento desconsidera o fato de que somente algumas pessoas querem migrar. Neste caso específico, a grande maioria dos mexicanos preferem continuar no seu país. 
essencialmente brancos. Há várias camadas de esquecimento envolvidas nesses processos.

Primeiro, o esquecimento da limpeza étnica e genocídio de povos originários, que possibilitou a colonização da América. No caso da Alemanha, houve um processo um tanto parecido de racialização e tentativa de limpeza étnica dos povos eslavos nas investidas, sem sucesso permanente, para conquistar e colonizar territórios ao leste.

Segundo, há o esquecimento da migração forçada de milhões de africanos à América, onde sua importação e escravização enriqueceu comerciantes e seu trabalho não remunerado enriqueceu muitos e contribuiu para estimular e possibilitar o desenvolvimento capitalista. Do lado europeu, há o esquecimento da importância do tráfico de escravos para o acúmulo de capital - sobretudo na Inglaterra, na Holanda e na França - e do papel do trabalho forçado de africanos e indígenas na extração de grandes quantidades de prata e ouro das colônias espanholas e portuguesas, que lubrificou os circuitos comerciais e estimulou as economias europeias. Finalmente, esquece-se do trabalho forçado de africanos e descendentes na produção de matérias-primas, principalmente algodão, para a revolução industrial, e estimulantes, especialmente açúcar e café, para as massas de trabalhadores da nova economia (Mintz, 1985; Grandin, 2014). Ou seja, o mito da "Europa branca" esquece dos milhões de indígenas americanos e africanos que participaram no desenvolvimento europeu, sem, porém, receber os benefícios.

Terceiro, a ideia da "imigração branca" só podia surgir com o esquecimento da racialização dos povos da periferia da Europa no passado, tratados como outras "raças" essencialmente inferiores. Os ingleses racializavam os irlandeses; os alemães racializavam os poloneses; os alemães, holandeses e franceses racializavam os italianos e outros povos do sul da Europa. Os protestantes do norte da Europa estabelecidos nos Estados Unidos e no Canadá racializavam os irlandeses, os eslavos e os latinos.

Quarto, o esquecimento da colonização, formal ou informal, de muitos dos países cujos habitantes hoje migram para os países centrais. Os povos colonizados aprenderam as línguas e as culturas das metrópoles e forneceram 
contribuições importantes às suas economias e guerras. Ao mesmo tempo, os colonizadores desenvolviam estereótipos dos colonizados, como o muçulmano "fanático e machista", o africano "ignorante e atrasado" ou o asiático "exótico", incapaz de se integrar nos países ocidentais - estereótipos que reaparecem hoje a respeito dos imigrantes originários das ex-colônias, repetidos na mídia, nos livros escolares (Weiner, 2016), nas campanhas de políticos nacionalistas da extrema direita, e recentemente promovidos pelas notícias falsas distribuídas nas mídias sociais por partidos da direita e pelo serviço não tão secreto da Rússia, até virarem parte do senso comum dos países centrais.

Quinto, o esquecimento da produção de imigrantes, inclusive de imigrantes "ilegais", pela conquista de impérios continentais. Muitos daqueles definidos como "imigrantes" ou "estrangeiros" são na realidade descendentes dos povos que já moravam anteriormente nos territórios conquistados, caso de muitos chicanos (descendentes de mexicanos) nos Estados Unidos ou de muitos poloneses presentes na Alemanha ao final do século XIX e início do XX.

Sexto, o esquecimento das múltiplas intervenções políticas do passado para inibir ou proibir a imigração de não europeus e manter a predominância de brancos nos principais países de imigração da Europa, da América do Norte e da Oceania.

Essas formas de amnésia social são perpetuadas pelas instituições e lugares da memória, que sistematicamente reprimem as memórias inconvenientes para as narrativas da formação de nações de brancos. A amnésia sobre o passado colonial e o passado das migrações influencia fortemente as percepções dos imigrantes não europeus atuais, o que permite a representação destes como intrusos sem vínculo com os países de imigração e incapazes de se integrar. Existem hoje, em vários países, conflitos políticos sobre a representação do passado, e as pesquisas de historiadores e sociólogos podem intervir nessas lutas pelo passado. 
Karl Martin Monsma é Professor de Sociologia na Universidade Federal do Rio Grande do Sul e pesquisador 1C do CNPq. Bolsista Capes, Estágio Sênior no Exterior. Bolsista CNPq, Produtividade em Pesquisa.

Đ karlmonsma@hotmail.com

Oswaldo Truzzi é Professor titular do Programa de Pós-Graduação em Sociologia da Universidade Federal de São Carlos e pesquisador 1B do CNPq. Bolsista CNPq, Produtividade em Pesquisa.

ఏtruzzi@ufscar.br

\section{Referências}

1. ANDERSON, Benedict. Imagined communities: reflections on the origin and spread of nationalism. 2. ed. Nova York: Verso, 1991.

2. ASSMANN, Jan; CZAPLICKA, John. Collective memory and cultural identity. New German Critique, n. 65, p. 125-33, primavera/verão, 1995.

3. BEISEL, Nicola. Imperiled innocents: Anthony Comstock and family reproduction in Victorian America. Princeton: Princeton University Press, 1997.

4. BEISEL, Nicola; KAY, Tamara. Abortion, race and gender in nineteenth century America. American Sociological Review, v. 69, p. 498-518, ago. 2004.

5. BLANC-CHALÉARD, Marie-Claude. Old and new migrants in France: Italians and Algerians. In: LUCASSEN, Leo; FELDMAN, David; OLTMER, Jochen (org.), Paths of integration: migrants in Western Europe (1880-2004). Amsterdã: Amsterdam University Press, 2006.

6. BOURDIEU, Pierre. A ilusão biográfica. In: FERREIRA, Marieta de M.; AMADO, Janaína (orgs.). Usos \& abusos da história oral. 5. ed. Rio de Janeiro: Editora FGV, 2002.

7. CASTLES, Stephen. Understanding global migration: a social transformation perspective. Journal of Ethnic and Migration Studies, v. 36, n. 10, p. 1565-86, dez. 2010.

8. CERTEAU, Michel de. L'écriture de I'histoire. Paris: Gallimard, 1975.

9. CHAMBERS, Henry L. Slavery, free blacks and citizenship. Rutgers Law Journal, v. 43, p. 487-513, 2013.

10. CHISHTI, Muzaffar; HIPSMAN, Faye; BALL, Isabel. Fifty years on, the 1965 Immigration and Nationality Act continues to reshape the United States. Migration Policy Institute, 15 out. 2015. Disponível em: < https://www.migrationpolicy. org/article/fifty-years-1965-immigration-and-nationality-act-continues-reshapeunited-states $>$. 
11. CLARKE, John. Historical amnesia: linking past, present and future in politics and policy. Research, Policy and Planning, v. 29, n. 3, p. 153-60, 2012.

12. COOPER, Frederick. Colonialism in question: theory, knowledge, history. Berkeley: University of California Press, 2005.

13. DIETZ, Barbara. Aussiedler in Germany: from smooth adaptation to tough integration. In: LUCASSEN, Leo; FELDMAN, David; OLTMER, Jochen (orgs.), Paths of integration: migrants in Western Europe (1880-2004). Amsterdã: Amsterdam University Press, 2006.

14. DOCTER, Koen. Cruel murderers, dangerous fanatics or exotic strangers: the representation of Muslims and Islam in the French and Dutch press in the late nineteenth century. Dissertação de Mestrado. (Human Geography and Planning), Utrecht University, 2011.

15. ELIAS, Norbert. Os alemães: a luta pelo poder e a evolução do habitus nos séculos XIX e XX. Rio de Janeiro: Editora Jorge Zahar, 1997.

16. ERNST, Stacy A. Indigenous sovereignty and settler amnesia: Robert Houle's premises for self rule. RACAR, Universities Art Association of Canada, v. 42, n. 2, p. 108-20, 2017.

17. FITZGERALD, David S.; COOK-MARTíN, David. Culling the masses: the democratic origins of racist immigration policy in the Americas. Cambridge: Harvard University Press, 2014.

18. FREDRICKSON, George M. Racism: a short history. Princeton: Princeton University Press, 2002.

19. FRISCH, Max. Vorwort. In: SEILER, Alexander J. Siamo italiani - die Italiener: Gespräche mit italienischen Arbeitern in der Schweiz. Zurique: EVZ Verlag, 1965.

20. GERSTLE, Gary. The contradictory character of American nationality: a historical perspective. In: FONER, Nancy; SIMON, Patrick. Fear, anxiety and national identity: immigration and belonging in North America and Western Europe. Nova York: Russell Sage Foundation, 2015.

21. GO, Julian. For a postcolonial sociology. Theory and Society, v. 42, n. 1, p. 25-55, 2013.

22. GRANDIN, Greg. The empire of necessity: slavery, freedom, and deception in the new world. Nova York: Metropolitan Books, 2014.

23. HERBERT, Ulrich. Geschichte der Ausländerpolitik in Deutschland: Saisonarbeiter, Zwangsarbeiter, Gastarbeiter, Flüchtlinge. Munique: Verlag D. H. Beck, 2001.

24. HOERDER, Dirk. Cultures in contact: world migrations in the second millennium. Durham: Duke University Press, 2002.

25. HOOCK, Silke. 24 Stunden, 7 Tage die Woche, 900 Euro Gehalt. Zeit Online, 15 maio 2016. Disponível em: <http://www.zeit.de/karriere/beruf/2016-05/ pflege-pflegekraefte-osteuropa-arbeitsbedingungen-deutschland $>$. 
26. HYLAND, Steve. Hacer América and the American dream: global migration and the Americas. Origins: Current Events in Historical Perspective, Ohio State University, v. 8, n. 8, maio 2015. Disponível em: <http://origins.osu.edu/ print/3022>.

27. JACOBSON, Matthew F. Whiteness of a different color: European immigrants and the alchemy of race. Cambridge: Harvard University Press, 1998.

28. LEE, Rhee-Soo. Constructing colonial binaries: French representations of religion in Algeria and Morocco. Trabalho de Conclusão de Curso (Bachelor of Arts), Wesleyan University, 2011.

29. LESSER, Jeffrey. Negotiating national identity: immigrants, minorities, and the struggle for ethnicity in Brazil. Durham: Duke University Press, 1999.

30. LIPSET, Seymour M.; RAAB, Earl. The politics of unreason: right wing extremism in America, 1790-1977. 2. ed. Chicago: University of Chicago Press, 1978.

31. LUCASSEN, Leo. Poles and Turks in the German Ruhr area: similarities and differences. In: LUCASSEN, Leo; FELDMAN, David; OLTMER, Jochen (orgs.). Paths of integration: migrants in Western Europe (1880-2004). Amsterdã: Amsterdam University Press, 2006.

32. LUCASSEN, Leo; FELDMAN, David; OLTMER, Jochen. Immigrant integration in Western Europe, then and now. In: LUCASSEN, Leo; FELDMAN, David; OLTMER, Jochen (orgs.), Paths of integration: migrants in Western Europe (18802004). Amsterdã: Amsterdam University Press, 2006.

33. LUCASSEN, Leo; LUCASSEN, Jan. The strange death of Dutch tolerance: the timing and nature of the pessimist turn in the Dutch migration debate. The Journal of Modern History, v. 87, n. 1, p. 72-101, mar. 2015.

34. MACHAQUEIRO, Mário. Ambivalent Islam: the identity construction of Muslims under Portuguese colonial rule. Social Identities, v. 18, n. 1, p. 39-63, jan. 2012.

35. MCKEOWN, Adam. Global migration, 1846-1940. Journal of World History, v. 15, n. 2, p. 155-89, jun. 2004.

36. MBEMBE, Achille. Crítica da razão negra. Lisboa: Antígona, 2014.

37. MENESES, Ulpiano T. B. de. A História, cativa da memória? Para um mapeamento da memória no campo das Ciências Sociais. Revista do Instituto de Estudos Brasileiros, v. 34, p. 9-24, 1992.

38. MILES, Robert. Racism after 'race relations'. Londres/Nova York: Routledge, 1993.

39. MINTZ Sidney W. Sweetness and power: the place of sugar in modern history. Nova York: Viking, 1985. 
40. MONSMA, Karl. Como pensar o racismo: o paradigma colonial e a abordagem da sociologia histórica. Revista de Ciências Sociais, Fortaleza, v. 48, n. 2, p. 5382, jul./dez., 2017

41. NOIRIEL, Gérard. Immigration: amnesia and memory. French Historical Studies, v. 19, n. 2, p. 367-80, outono 1995.

42. NORA, Pierre. Entre memória e história: a problemática dos lugares. Projeto História, São Paulo, n. 10, p. 7-28, dez. 1993.

43. OLICK, Jeffrey K.; ROBBINS, Joyce. Social memory studies: from "collective memory" to the historical sociology of mnemonic practices. Annual Review of Sociology, v. 24, p. 105-40, 1998.

44. OLTMER, Jochen. 'To live as Germans among Germans.' Immigration and integration of 'ethnic Germans' in the German Empire and the Weimar Republic. In: LUCASSEN, Leo; FELDMAN, David; OLTMER, Jochen (orgs.), Paths of integration: migrants in Western Europe (1880-2004). Amsterdã: Amsterdam University Press, 2006.

45. PETERS-SCHILDGEN, Susanne. Tagungsbericht: "Polen im Ruhrgebiet 1870 - 1945" - Deutsch-polnische Tagung, 06.11.2003 - 09.11.2003 Bochum. H-SozKult, 14 dez. 2003. Diponível em: <https://www.hsozkult.de/conferencereport/ id/tagungsberichte-352>.

46. POLLAK, Michael. Memória e identidade social. Estudos Históricos, Rio de Janeiro, v. 5, n. 10, p. 200-12, 1992.

47. PÖTTGER, Horst. Zu verdeutscht: die Mär von den integrierten Ruhr-Polen. Zeit - Online, 26 fev. 2015. Disponível em: <http://www.zeit.de/2015/07/ integration-migration-ruhr-polen $>$.

48. POYNTING, Scott; MASON, Victoria. The resistible rise of Islamophobia: antiMuslim racism in the UK and Australia before 11 September 2001. Journal of Sociology, v. 43, n. 1, p. 61-86, 2007.

49. PRIES, Ludger; BEKASSOW, Natalia. Discriminação e racismo na União Europeia: diagnóstico de uma ameaça negligenciada e da investigação científica correspondente. Sociologias, Porto Alegre, v. 17, n. 40, p. 176-211, set./dez. 2015.

50. QUIJANO, Aníbal. Colonialidad del poder, eurocentrismo y América Latina. In: LANDER, Edgardo (org.). La colonialidad del saber: eurocentrismo y ciencias sociales. Perspectivas latinoamericanas. Buenos Aires: CLACSO, 2000.

51. REINECKE, Christiane. Governing aliens in times of upheaval: immigration control and modern state practice in early twentieth-century Britain, compared with Prussia. International Review of Social History, v. 54, n. 1, p. 39-65, abr. 2009.

52. SAEED, Amir. Media, racism and Islamophobia: the representation of Islam and Muslims in the media. Sociology Compass, v. 1, n. 2, p. 443-62, 2007. 
53. SAID, Edward. Orientalism. Londres: Routledge, 1978.

54. SAID, Edward; JHALLY, Sut. Edward Said: on 'Orientalism'. Media Education Foundation, 2005. Disponível em: <http://www.mediaed.org/transcripts/EdwardSaid-On-Orientalism-Transcript.pdf $>$.

55. SAKURAI, Celia. Imigração japonesa para o Brasil: um exemplo de imigração tutelada (1908-1941). In: FẢUSTO, Boris (org.). Fazer a América: a imigração em massa para a América Latina. São Paulo: EdUSP, 1999.

56. SCHÖNWALDER, Karen. Assigning the State its rightful place? Migration, integration and the State in Germany. In: LUCASSEN, Leo; FELDMAN, David; OLTMER, Jochen (orgs.). Paths of integration: migrants in Western Europe (18802004). Amsterdã: Amsterdam University Press, 2006.

57. SKIDMORE, Thomas E. Black into white: race and nationality in Brazilian thought. Durham: Duke University Press, 1993.

58. STEINMETZ, George. The Devil's handwriting: precoloniality and the German colonial state in Qingdao, Samoa, and Southwest Africa. Chicago: University of Chicago Press, 2007.

59. TILLY, Charles. Coerção, capital e Estados europeus, 990-1992. São Paulo: EdUSP, 1996.

60. VINITZKY-SEROUSSI; Vered; TEEGER, Chana. Unpacking the unspoken: silence in collective memory and forgetting. Social Forces, v. 88, n. 3, p. 110322, mar. 2010.

61. VOLPP, Leti. Impossible subjects: illegal aliens and alien citizens. Michigan Law Review, v. 103, p. 1595-630, maio 2005.

62. WATERS, Mary C.; KASINITZ, Philip. The war on crime and the war on immigrants: racial and legal exclusion in the twenty-first century United States. In: FONER, Nancy; SIMON, Patrick. Fear, anxiety and national identity: immigration and belonging in North America and Western Europe. Nova York: Russell Sage Foundation, 2015.

63. WEINER, Melissa F. O fardo holandês: escravidão, África e imigrantes nos livros de história da escola primária na Holanda. Sociologias, Porto Alegre, v. 17, n. 40, p. 212-54, set./dez. 2015.

64. WOLF, Eric R. Europe and the people without history. Berkeley: University of California Press, 1982.

Recebido: 12 abr. 2018

Aceito: 24 set. 2018 